\title{
Kesan Integriti Pemerisaian Sinaran Seramik Mullite-Barite (MBC) terhadap Kejadian Kebakaran
}

(Radiation Shielding Integrity of Mullite-Barite Ceramic (MBC) due to Fire Events)

\author{
AZUHAR RIPIN, FAIZAL MOHAMED*, MOHD IDZAT IDRIS \& NUR SYAFIKA SUHAIMIN
}

\begin{abstract}
Mullite-barite ceramic (MBC) prototype which contains a major phase of barium aluminosilicate (BAS) mineral is an anti-radiation ceramics which is derived from Malaysian kaolin Akima-35 and local barites using conventional ceramics processing route. $M B C$ is a low cost and high performance ceramics which resistance to fire events are fabricated and characterised according to their microstructure properties and radiation test to ensure the shielding capability of the ceramics. The MBC will be used as shielding materials for walls, floor and ceiling of medical x-ray radiation facilities in clinics, medical centers and hospitals. The prepared $M B C$ was undergoing microstructure analysis using X-ray diffraction (XRD) and Scanning Field Electron Microscope (FESEM) to see the phase and morphological of the ceramics. Lead equivalent (LE) and homogeneity test was carried out to evaluate the shielding performance of the MBC before the ceramics are fired with different building fire temperature. The temperature used to simulate the fire events are 400, 900, and $1100^{\circ} \mathrm{C}$ which is burnt in the high temperature electrical furnace. The fired $M B C$ once again underwent XRD and FESEM to see any changes in the phase and morphology. The lead equivalent and homogeneity test also repeated to see the changes in the shielding performance. From the study, the microstructure analysis from XRD and FESEM obtained shows no significant changes of Monoclinic Barium Aluminosilicate (BAS), which are the major shielding phase in the ceramics before and after fire events. The lead equivalent test and homogeneity also remains the same before and after fire events with the maximum LE calculated are $0.38 \mathrm{~mm} \mathrm{~Pb}$ and 3.6\% of homogeneity. From the study, it can be concluded that if the fire event occurred in the radiation facilities, the shielding performance and integrity of the shielding will be remained and the temperature will not degraded the shielding capabilities of the ceramics as do happen for a conventional shielding material.
\end{abstract}

Keywords: Lead equivalent thickness; medical X-ray; mullite-barite ceramics (MBC); radiation shielding

ABSTRAK

Prototip seramik mullite barite (MBC) yang mengandungi fasa utama mineral barium aluminosilikat (BAS) merupakan seramik anti-sinaran yang dihasilkan daripada kaolin Malaysia akima-35 dan serbuk barite tempatan melalui kaedah pemprosesan seramik konvensional. MBC akan digunakan sebagai bahan perlindungan sinaran untuk dinding, lantai dan juga siling bagi kemudahan sinar-X perubatan di klinik, pusat perubatan dan juga hospital. MBC yang disediakan akan menjalani analisis struktur mikro menggunakan teknik serakan sinar-X (XRD) dan mikroskop imbasan medan elektron (FESEM) terutamanya bagi penentuan fasa serta morfologi seramik yang terhasil. Ujian ketebalan kesetaraan plumbum (LE) dan keseragaman dijalankan bagi menilai prestasi pemerisaian MBC sebelum dan selepas dibakar. Suhu simulasi kebakaran bangunan yang digunakan adalah 400, 900 dan $1100^{\circ} \mathrm{C}$ yang dibakar di dalam relau elektrik bersuhu tinggi. MBC yang dibakar ini akan sekali lagi melalui ujian XRD dan FESEM bagi melihat sebarang perubahan fasa dan morfologi sampel seramik tersebut. Ujian ketebalan kesetaraan plumbum dan keseragaman sekali lagi ditentukan bagi melihat perubahan prestasi pemerisaian. Daripada analisis struktur mikro menerusi XRD dan FESEM didapati tiada perubahan fasa Barium Aluminosilicate (BAS) yang signifikan berlaku bagi seramik sebelum dan selepas kebakaran. Keputusan ujian ketebalan kesetaraan plumbum dan keseragaman juga tetap sama direkodkan bagi MBC sebelum dan selepas kebakaran berlaku dengan ketebalan maksimumnya adalah $0.38 \mathrm{mmPb}$ dan $3.6 \%$ keseragaman direkodkan. Daripada kajian ini dapat disimpulkan bahawa jika berlakunya kebakaran pada kemudahan penyinaran, prestasi pemerisaian dan keseragaman MBC dijangka tidak berubah seperti yang berlaku pada bahan perlindungan konvensional.

Kata kunci: Ketebalan kesetaraan plumbum; perisai perlindungan sinaran; seramik mullite-barite (MBC); sinar-X perubatan

\section{PENGenalan}

Bahan perlindungan sinaran yang biasa digunakan pada kemudahan mesin sinar-X perubatan adalah didominasi oleh penggunaan kepingan plumbum, konkrit dan plaster sinar-X. Penggunaan konkrit dan plaster sinar-X digunakan pada bahagian dinding bilik sinaran, manakala 
pada bahagian pintu pula biasanya kepingan plumbum akan digunakan disebabkan oleh faktor kos yang tinggi jika digunakan pada keseluruhan bahagian dinding bilik sinaran. Harga pasaran dunia yang tinggi bagi plumbum sekitar USD 2400 satu tan metrik menyebabkan keperluan kepada perisai perlindungan sinaran alternatif yang lebih murah dan efisien diperlukan (Infomine 2017). Selain daripada faktor harga bahan mentah bagi perisai perlindungan sinaran, faktor ketahanan pemerisaian bahan sinaran jika berlakunya bencana alam juga merupakan faktor penting yang perlu diambil kira bagi membangunkan perisai perlindungan sinar- $X$ yang baru. Salah satu bencana alam yang paling kerap berlaku di Malaysia adalah kebakaran bangunan. Kadar kebakaran bangunan yang tinggi dengan purata 33,640 kes pada tahun 2013 yang melibatkan seramai 70 kematian dan 165 kecederaan dengan kerugian yang dianggarkan sebanyak 2 billion ringgit yang berlaku pada tahun tersebut sahaja (Rahim 2015). Berdasarkan kepada pecahan statistic, 90\% kebakaran adalah berpunca daripada kecuaian manusia dan melibatkan bangunan seperti rumah kediaman, bangunan pejabat, kedai, bengkel, stor, sekolah, bangunan awam serta kilang (Utusan 1998). Kebakaran bangunan akan menyebabkan prestasi pemerisaian bagi kemudahan sinaran akan merosot kerana integriti dinding, lantai dan pintu bilik sinaran juga akan menurun disebabkan kerosakan pada bahagian tersebut. Kerosakan utama datangnya daripada rekahan yang terhasil daripada regangan dan penghidratan haba kesan daripada kebakaran. Prestasi pemerisaian akan terkesan dan menurun mengikut rekahan sais geometri (lebar, dalam dan lengkungan) dan kadar dos pada permukaan luar kemudahan sinaran akan meningkat secara logaritma selari dengan peningkatan saiz rekahan (Keshk et al. 2012). Berdasarkan kepada kajian terdahulu, kesan pendedahan jangka panjang kepada suhu tinggi menunjukkan kekuatan mampatan konkrit akan berkurang. Kekuatan mampatan akan berkurang pada suhu $540^{\circ} \mathrm{C}$. Bagi konkrit konvensional, pendedahan jangka panjang kepada suhu tinggi boleh menyebabkan perubahan dalam kekuatan mampatan, modulus keanjalan, rintangan rayapan, kekonduksian, kekenyalan dan pengembangan (Kodur 2014). Secara umumnya, ambang pengurangan dalam konkrit akan berlaku pada suhu $95^{\circ} \mathrm{C}$. Kesan jelas perubahan suhu pada konkrit adalah pada kekuatan regangan dengan peningkatan suhu daripada $20^{\circ} \mathrm{C}$ kepada $100^{\circ} \mathrm{C}$ boleh mengurangkan $50 \%$ daripada kekuatan tensil sesuatu konkrit (Filmore 2004).

Bagi mengatasi masalah ini, buat pertama kalinya perisai sinaran berasaskan seramik mulitte-barite (MBC) dihasilkan melalui komposisi terbaik kaolin Malaysia AKIMA 35 sebagai asas pembentukan mullite dan barite sebagi penguat kepada struktur seramik anti sinaran. Seramik yang terhasil telah berjaya meningkatkan keupayaan pemerisian dos sinaran sehingga $97.42 \%$ dan boleh digunakan sebagai perisai sinaran untuk kemudahan sinar-X perubatan (Ripin et al. 2018). Di samping keupayaan pemerisian $\mathrm{MBC}$ terhadap sinar-X dalam julat diagnostik, prestasi MBC terhadap suhu kebakaran juga dikaji dalam kertas ini melalui simulasi kebakaran dengan suhu yang berbeza. Berdasarkan kepada keputusan yang diperoleh, integriti pemerisaian serta struktur mikro sebelum dan selepas masih mengekalkan prestasi yang sama walaupun berlakunya kebakaran. Atas faktor ini, perisai sinaran tempatan MBC ini amat sesuai digunakan sebagai perisai bagi bilik sinaran serta mampu mengekalkan prestasi pemerisianya walaupun berlakunya bencana alam seperti kebakaran bangunan.

\section{BAHAN DAN KAEDAH UJI KAJI}

\section{PENGHASILAN PROTOTAIP SERAMIK MULLITE BARITE}

Seramik mullite barite (MBC) dihasilkan dengan menggunakan kaedah penghasilan seramik konvensional iaitu melalui proses pengeringan, penghancuran, percampuran serbuk, pemampatan dan proses pembakaran. Proses pengeringan serbuk kaolin Akima-35 dan barite dijalankan dengan menggunakan ketuhar elektrik Carbolite dengan suhu $105^{\circ} \mathrm{C}$ selama 8 jam sehari dan mengambil masa selama 3 hari bagi memastikan kelembapan pada kedua-dua serbuk tadi hilang sepenuhnya. Kemudian serbuk ini akan dicampurkan mengikut peratusan $60 \%$ serbuk kaolin dan $40 \%$ serbuk barits berdasarkan berat campuran serbuk tadi akan dikisar dan dihancurkan menggunakan pengisar bebola Pulverisssate Planetry selama 30 min dengan kelajuan $300 \mathrm{rpm}$. Bebola yang digunakan untuk mengisar serbuk tersebut adalah daripada jenis tungsten karbid sebanyak 8 biji bebola. Serbuk yang siap dikisar seterusnya dibakar dengan menggunakan relau elektrik bersuhu tinggi Nabertherm dengan menggunakan suhu $400^{\circ} \mathrm{C}$ dan ditetapkan selama 30 min dan seterusnya suhu maksimum $1300^{\circ} \mathrm{C}$ pula dikenakan selama 2 jam dan dibiarkan sejuk pada suhu bilik semalaman. Proses penghasilan seramik mullite barite secara terperinci diterangkan dalam artikel ' $X$-ray shielding behaviour of kaolin derived mullite- barites ceramic' (Ripin et al. 2018).

Prototaip MBC akan menjalani proses pencirian seterusnya iaitu pencirian struktur mikro dengan menggunakan mesin serakan sinar-X (XRD) dan mikroskop imbasan medan elektron (FESEM). Pencirian seterusnya adalah pencirian kesan sinaran yang melibatkan ujian ketebalan kesetaraan plumbum (LE) dan keseragaman.

\section{UJIAN STRUKTUR MIKRO PROTOTAIP MBC}

Pembentukan fasa MBC ditentukan dengan menggunakan mesin serakan sinar-X (XRD) Bruker AXS D8 Advance dan morfologi permukaan seramik ditentukan dengan menggunakan FESEM, Zeiss GeminiSEM 500 dengan sudut $17^{\circ}$ hingga $70^{\circ}$. Pengiraan peratusan pembentukan fasa pula akan ditentukan menggunakan X'PertHighScore Plus. Ujian struktur mikro juga diulang bagi sampel MBC yang akan dibakar pada suhu $400^{\circ} \mathrm{C}, 900^{\circ} \mathrm{C}$ dan $1100^{\circ} \mathrm{C}$ bagi melihat perubahan fasa dan morfologi apabila berlakunya kebakaran. 


\section{UJIAN KETEBALAN KESETARAAN PLUMBUM DAN KESERAGAMAN (LE)}

Pengukuran ketebalan kesetaraan plumbum (LE) dijalankan dengan membandingkan ketebalan kepingan plumbum berketulenan tinggi $99.9 \%$ dengan sampel MBC yang telah disiapkan. Pengukuran dilakukan berdasarkan IEC61331-1:2014 dengan menggunakan alur sinar-X kualiti perubatan daripada mesin sinar-X Am Toshiba-KXO50s. Hukum pengecilan sinaran digunakan bagi menghasilkan lengkungan kalibrasi piawaian bagi plumbum berketulenan tinggi tersebut (Buermann et al. 2016).

Bagi menentukan keseragaman sampel MBC, dos pengecilan sinaran pada lima posisi berlainan pada setiap sampel akan diambil dan nilai pekali perubahan (COV) atau ralat piawaian akan dihitung bagi melihat perbezaan nilai pengecilan pada posisi yang berlainan dalam peratusan.

Pengiraan ketebalan kesetaraan plumbum (LE) dan keseragaman ini akan dihitung bagi sampel sebelum dan selepas ujian kebakaran untuk melihat perubahan prestasi pemerisaian sampel tersebut.

\section{PEMBAKARAN SAMPEL MBC TERHADAP SUHU KEBAKARAN BANGUNAN BERBEZA}

Sebanyak empat set sampel yang dinomborkan sebagai F1, F2, F3 dan F4 dibakar pada suhu kebakaran berbeza seperti pada Jadual 1.

JADUAL 1. Suhu pembakaran bagi sampel F1, F2, F3 dan F4 bagi ujian kebakaran

\begin{tabular}{ccc}
\hline Bil. & Sampel MBC & Suhu dibakar $\left({ }^{\circ} \mathrm{C}\right)$ \\
\hline 1 & F1 & 0 (tiada pembakaran) \\
2 & F2 & 400 \\
3 & F3 & 900 \\
4 & F4 & 1100 \\
\hline
\end{tabular}

Pembakaran telah dilakukan di dalam relau Muffle $1700^{\circ} \mathrm{C}$ Model BSK-1700X-M selama empat jam. Sampel MBC yang siap dibakar ini akan sekali lagi melalui ujian XRD, SEM dan ujian ketebalan kesetaraan plumbum dan keseragaman.

\section{KEPUTUSAN DAN PERBINCANGAN}

\section{SERAMIK MULLITE BARITE (MBC)}

Proses penghasilan seramik secara konvensional yang digunakan ini telah berjaya menghasilkan seramik putih berbentuk cakera yang mempunyai permukaan licin berdiameter $4 \mathrm{~cm}$ dan berketebalan $0.5 \mathrm{~cm}$ seperti dalam Rajah 1.

Berdasarkan kepada ujian XRD, didapati fasa tunggal yang terbentuk pada struktur mikro seramik mullite barite adalah fasa celsian yang juga dikenali sebagai fasa monoklinik barium aluminosilikat (BAS). Kesemua sampel yang terhasil menghasilkan fasa BAS seperti

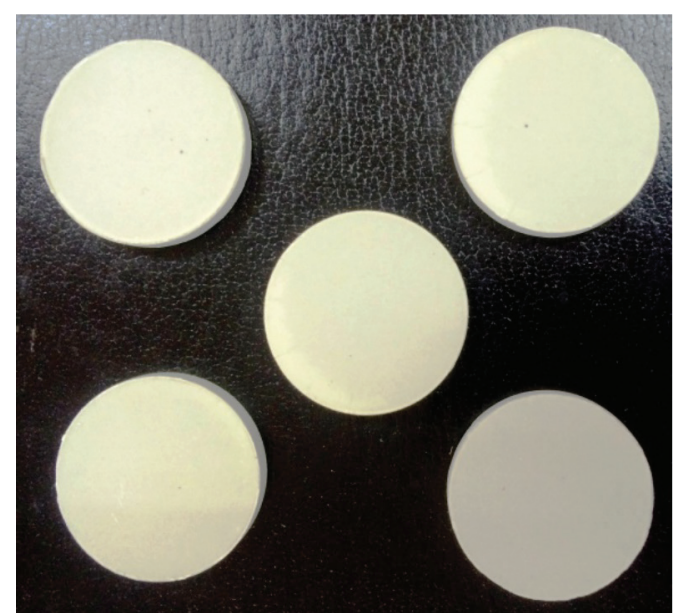

RAJAH 1. Seramik mullite barits (MBC) yang dihasilkan melalui kaedah pemprosesan seramik konvensional

yang telah dijangka. Saiz pengkristalan yang besar jelas kelihatan pada spektrum yang terhasil.

Manakala bagi sampel MBC yang ditandakan sebagai F1, F2, F3 dan F4, fasa tunggal celsian terbentuk pada kesemua sampel seramik yang melalui proses pembakaran dan yang tidak melalui proses pembakaran. Tiada perubahan daripada segi fasa pengkristalan yang dicerap oleh pembelauan sinar-X (XRD) untuk sampel seramik tersebut. Rajah 2 merupakan kombinasi spektrum yang diperoleh melalui teknik XRD untuk sampel seramik F1, F2, F3 dan F4.

BAS banyak digunakan sebagai bahan refrektori disebabkan oleh ketahanannya kepada suhu tinggi dengan suhu penggunaan BAS adalah $1590^{\circ} \mathrm{C}$ dan takat lebur bagi BAS adalah $1760^{\circ} \mathrm{C}$. Menurut Bansal et al. (2003), jika suhu di bawah takat lebur dikenakan kepada sesuatu bahan yang mempunyai fasa tunggal monoklinik BAS, maka tiada perubahan fasa akan berlaku kepada sesuatu bahan tersebut.

Analisis menggunakan Rietvield pula menunjukkan sedikit perubahan pada ketegangan mikro, saiz pengkristalan dan juga anggaran ketumpatan seperti yang ditunjukkan pada Jadual 2. Perbezaan nilai ketegangan mikro yang berlaku untuk setiap sampel MBC yang mengalami simulasi kebakaran adalah sangat rendah dan hampir sama iaitu di bawah $0.1 \%$ menunjukkan bahawa tenaga daripada suhu kebakaran yang dikenakan kepada sampel tersebut tidak dapat mengubah bentuk struktur mikro bagi setiap sampel MBC dan ia juga disokong oleh tiadanya perubahan yang berlaku kepada sistem kristal dan juga saiz pengkristalan yang terhasil. Perkara ini disahkan oleh Drummond dengan BAS atau celsian ini akan berada dalam fasa stabil dan tidak berlaku sebarang perubahan pada fasa yang terbentuk jika suhu yang dikenakan adalah di bawah $1590^{\circ} \mathrm{C}$. Selain daripada itu, nilai tegangan mikro juga tidak banyak berubah disebabkan oleh sifat celsian itu sendiri yang mempunyai nilai pekali pengembangan haba yang rendah iaitu 2.29 $\times 10^{-6} /{ }^{\circ} \mathrm{C}$ (Drummond et al. 1990). 


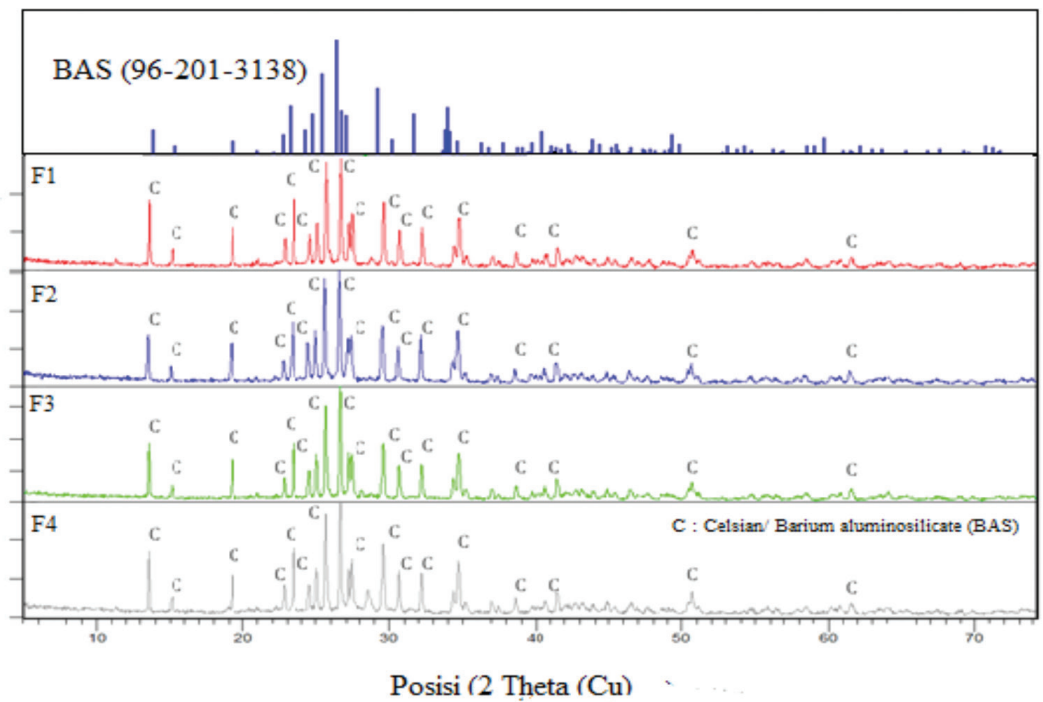

RAJAH 2. Profil XRD bagi sampel F1, F2, F3 dan F4 yang telah melalui proses pembakaran sehingga $1100^{\circ} \mathrm{C}$

JADUAL 2. Nilai ketegangan mikro, saiz pengkristalan dan ketumpatan menggunakan ujian Rietveld bagi F1, F2, F3 dan F4

\begin{tabular}{|c|c|c|c|c|c|}
\hline Bil. & Sampel & Sistem kristal & $\begin{array}{c}\text { Ketegangan } \\
\text { mikro }(\%)\end{array}$ & $\begin{array}{c}\text { Saiz pengkristalan } \\
(\AA)\end{array}$ & $\begin{array}{l}\text { Ketumpatan } \\
\left(\mathrm{g} / \mathrm{cm}^{3}\right)\end{array}$ \\
\hline 1. & $\mathrm{~F} 1$ & $\begin{array}{l}\text { Monoklinik Barium } \\
\text { Aluminosilikat (BAS) }\end{array}$ & 0.119 & 27913.400 & 3.23 \\
\hline 2. & $\mathrm{~F} 2$ & $\begin{array}{l}\text { Monoklinik Barium } \\
\text { Aluminosilikat (BAS) }\end{array}$ & 0.120 & 27913.400 & 3.23 \\
\hline 3. & F3 & $\begin{array}{c}\text { Monoklinik Barium } \\
\text { Aluminosilikat (BAS) }\end{array}$ & 0.129 & 27913.400 & 3.15 \\
\hline 4. & $\mathrm{~F} 4$ & $\begin{array}{l}\text { Monoklinik Barium } \\
\text { Aluminosilikat (BAS) }\end{array}$ & 0.104 & 27913.400 & 3.15 \\
\hline
\end{tabular}

Kehadiran fasa monoklinik barium aluminosilikat (BAS) pada setiap sampel F1-F4 disokong oleh imej morfologi yang didapati daripada teknik mikroskop imbasan medan elektron (FESEM). Kesemua imej yang diperoleh menunjukkan kehadiran kepingan barium aluminosilikat yang menjadi fasa utama dalam pemerisaian sinaran mengion. Ini disokong dengan spektrum EDX pada setiap Rajah 3(a)-3(d). Saiz pengkristalan yang besar serta padat yang mencapai sehingga $27913 \AA$ merupakan fasa yang sangat bagus bagi pengecilan foton yang melalui seramik tersebut (Amritphale et al. 2007a, 2007b). Anggaran ketumpatan bagi seramik MBC ini juga agak tinggi iaitu sekitar $3.2 \mathrm{~g} / \mathrm{cm}^{3}$ dan ia lebih tinggi berbanding konkrit berketumpatan kategori berat iaitu $2.6 \mathrm{~g} / \mathrm{cm}^{3}$ yang banyak digunakan sebagai perisai pada kemudahan penyinaran. Seramik MBC ini boleh dikategorikan sebagai konkrit berketumpatan tinggi kerana mempunyai ketumpatan melebihi $3 \mathrm{~g} / \mathrm{cm}^{3}$ mengikut TS-EN 206-1 (2002) (Ouda 2015).

Ketebalan kesetaraan plumbum bagi setiap sampel MBC sebelum dan selepas kejadian kebakaran dihitung berdasarkan lengkungan kalibrasi piawaian pada Rajah 4 adalah seperti pada Rajah 5.
Berdasarkan kepada nilai ketebalan kesetaraan plumbum sampel seramik yang diukur di dalam makmal, julat nilai ketebalan kesetaraan plumbum adalah antara $0.25-0.37 \mathrm{mmPb}$ bagi sampel MBC sebelum berlakunya simulasi kebakaran di dalam relau. Ketebalan maksimum yang direkodkan adalah pada $0.37 \mathrm{mmPb}$ yang diukur pada keupayaan tiub sinar-X pada $90 \mathrm{kV}$. Manakala bagi sampel seramik yang dibakar di dalam relau pada suhu berbeza $400^{\circ} \mathrm{C}, 900^{\circ} \mathrm{C}$ dan $1100^{\circ} \mathrm{C}$ yang ditandakan sebagai $\mathrm{F} 2-\mathrm{F} 4$ nilai ketebalannya adalah pada julat $0.26-0.38 \mathrm{mmPb}$ iaitu lebih tinggi sedikit yang dicerap berbanding ketebalan sebelum dibakar.

Ketebalan maksimumnya adalah $0.38 \mathrm{mmPb}$ yang didapati pada sampel F2 pada keupayaan tiub $90 \mathrm{kV}$ mesin sinar-X. Walau bagaimanapun, berdasarkan kepada sampel yang dibakar pada suhu yang berbeza, didapati tiada sebarang perubahan ketebalan signifikan ditunjukkan. Perkara ini adalah disebabkan tiada perubahan pada fasa struktur mikro dan morfologi seramik tersebut walaupun ia dibakar pada suhu tinggi sehingga $1100^{\circ} \mathrm{C}$ seperti yang diberikan oleh keputusan XRD dan FESEM. Nilai ketebalan kesetaraan plumbum bagi sampel seramik ini tidak banyak berubah dan ia masih mengekalkan tahap 


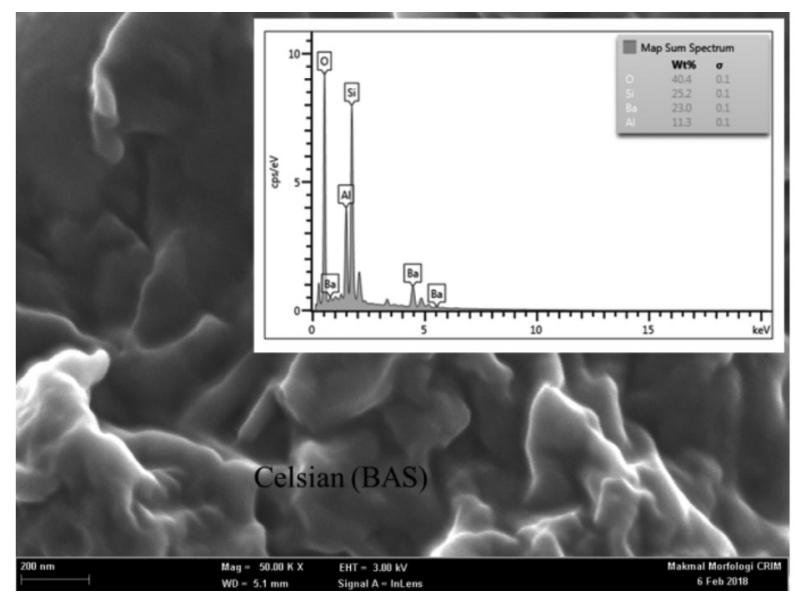

RAJAH 3(a). Sampel F1 terdapat kehadiran fasa barium aluminosilikat (BAS)

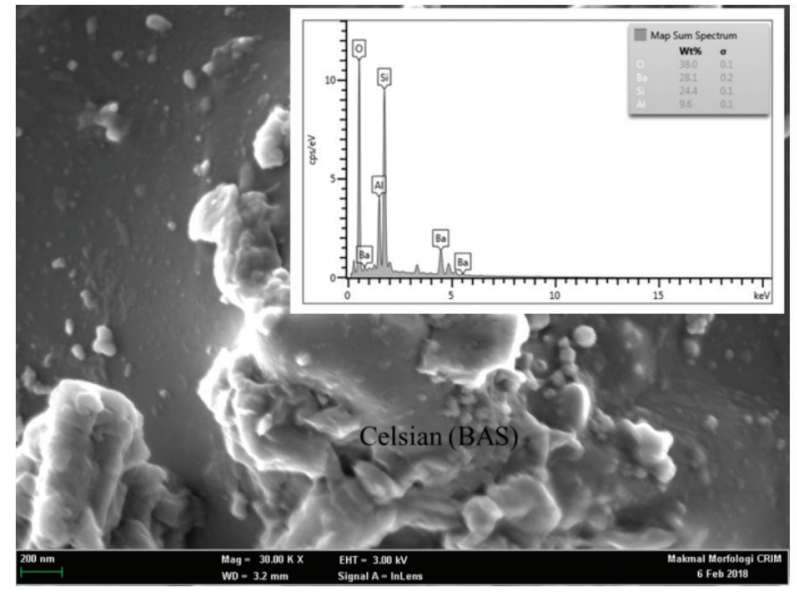

RAJAHH 3(c). Sampel F3 terdapat kehadiran fasa barium aluminosilikat (BAS)

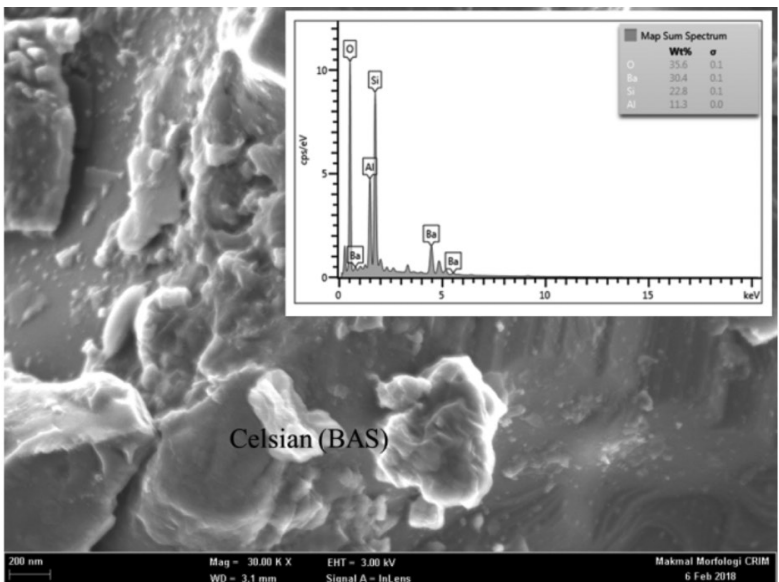

RAJAH 3(b). Sampel F2 terdapat kehadiran fasa barium aluminosilikat (BAS)

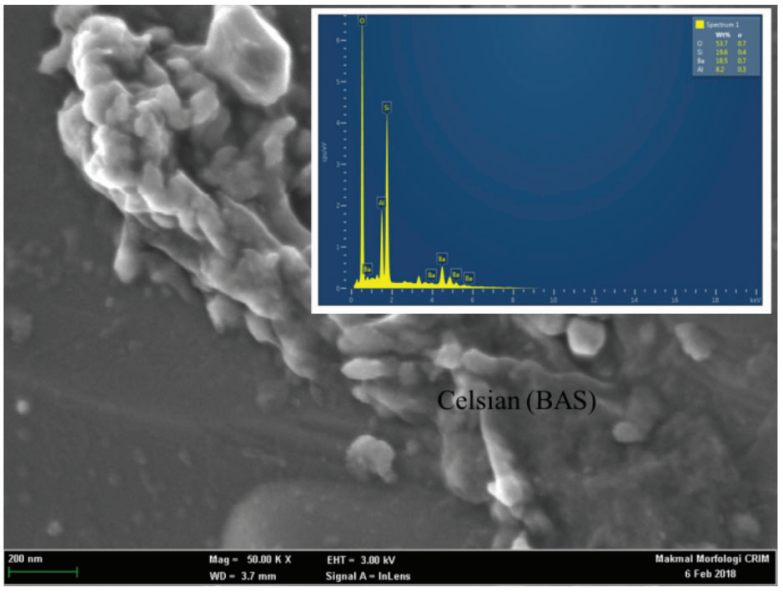

RAJAH 3(d): Sampel F4 terdapat kehadiran fasa barium aluminosilikat (BAS)

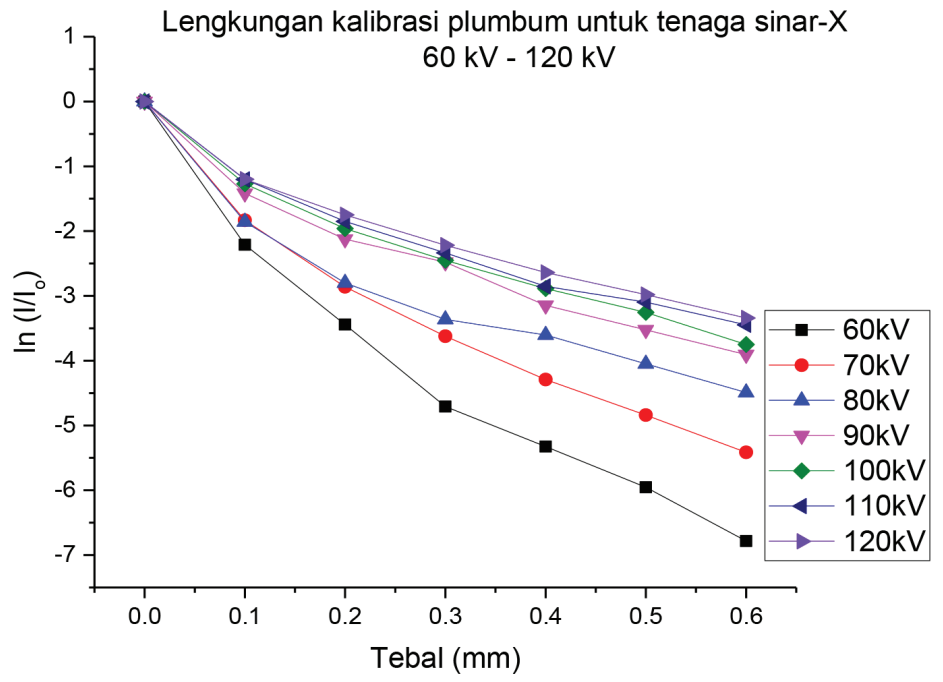

RAJAH 4. Graf lengkungan kalibrasi bagi kepingan plumbum bagi tenaga sinar-X diagnostik (60 kV sehingga $120 \mathrm{kV})$ 

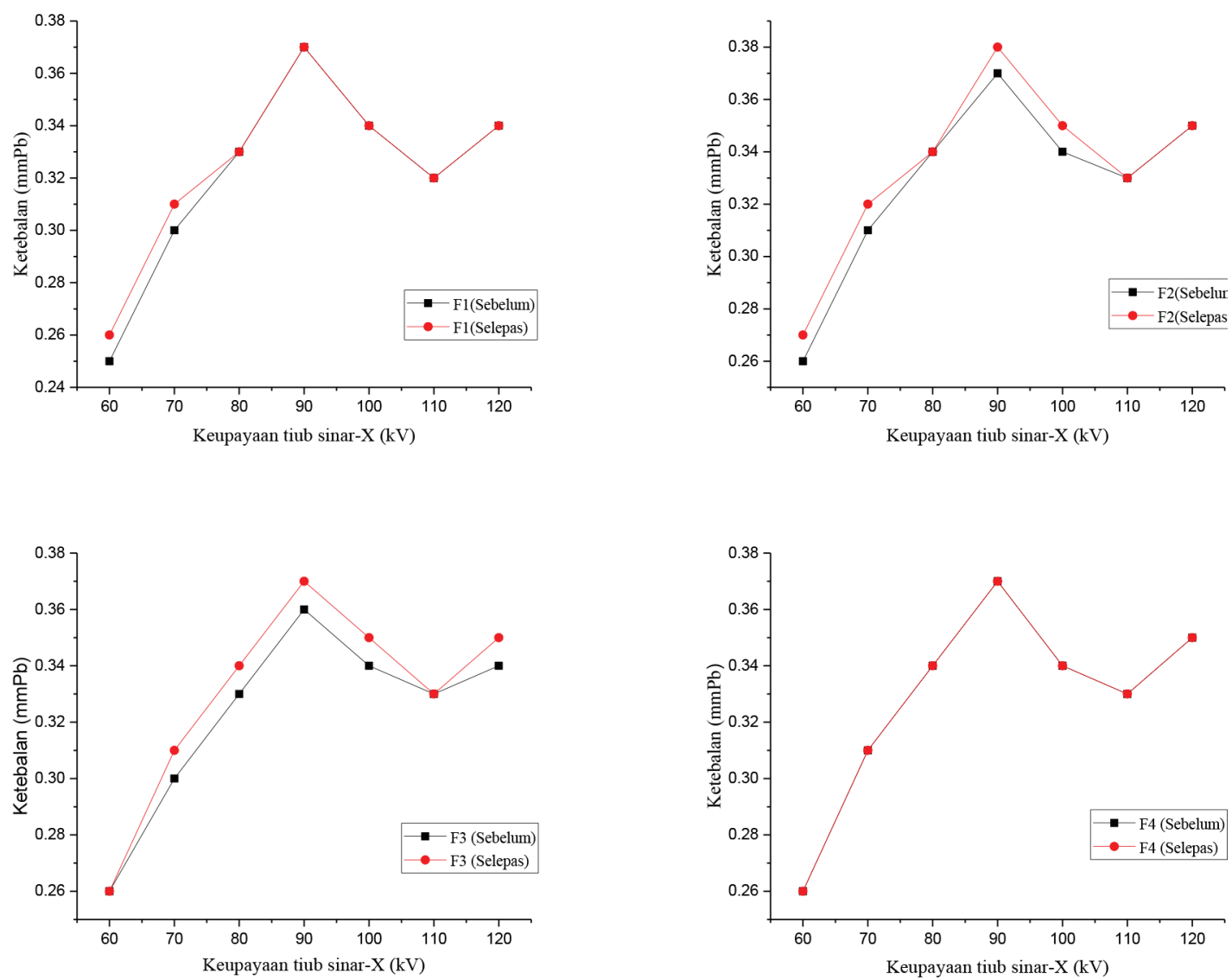

RAJAH 5. Ketebalan kesetaraan plumbum (mmPb) bagi sampel F1, F2, F3 dan F4 sebelum dan selepas kebakaran $\mathrm{X}$ pada julat tenaga sinar-X perubatan $(60-120 \mathrm{kV})$ dengan F1 (tiada kebakaran), F2 (dibakar pada suhu $400^{\circ} \mathrm{C}$ ), F3 (dibakar pada suhu $900^{\circ} \mathrm{C}$ ) dan $\mathrm{F} 4$ (dibakar pada suhu $1100^{\circ} \mathrm{C}$ )

pemerisaian sinar-X walaupun terbakar pada suhu yang tinggi disebabkan oleh ketahanan seramik tersebut terhadap kadar tekanan haba adalah sangat baik. Bagi seramik yang homogen dan isotropik seperti sampel MBC ini, tiada tekanan pada struktur bahan akan meningkat walaupun terdapat perubahan suhu baru yang diberikan kepada sampel tersebut (Kingrey 1955). Tekanan ini sebenarnya akan menyebabkan tekanan haba yang mendorong seramik tersebut akan mengembang dan seterusnya akan menyebabkan berlakunya retakan yang akhirnya merubah tahap pemerisaian bagi sesuatu bahan perlindungan sinaran. Jika seramik tersebut tidak homogen dan isotropik, tekanan akan berlaku disebabkan oleh pengembangan antara kristal atau fasa yang berbeza di dalam struktur seramik tersebut (Kingrey 1955). Bagi MBC, ini tidak berlaku kerana ia mempunyai satu fasa celsian atau fasa barium aluminosilikat (BAS) sahaja. Fasa ini berada dalam keadaan stabil dan tidak akan berlaku perubahan fasa jika suhu yang dikenakan berada di bawah takat leburnya (Bansal et al 1992).

Nilai keseragaman bagi setiap sampel MBC diukur pada tiga tempat berbeza pada setiap set sampel seramik. Keseragaman sebelum dan selepas simulasi kebakaran agak sama dan sedikit rawak berbanding dengan ketabalan kesetaraan plumbum. Walau bagaimanapun, nilai keseragaman ini masih boleh diterima kerana keseragaman maksimum adalah pada $3.6 \%$ dalam bidang perubatan bagi tujuan perlindungan sinaran nilai piawaian kebolehulangan ouput sinaran bagi ujian kawalan mutu (QC) mesin sinar-X adalah pada kadar 5\% (KKM 2017).

\section{KESIMPULAN}

Prestasi cemerlang pemerisian sinaran bagi prototaip MBC ditunjukkan melalui ujian ketebalan kesetaraan plumbum (LE) dan keseragaman dengan mengekalkan ketebalan serta keseragaman pada semua sampel MBC sebelum dan selepas simulasi kebakaran dijalankan. Manakala sifat struktur mikro utama iaitu matriks barium aluminosilikat (BAS) yang menjadi fasa pemerisaian sinaran bagi seramik ini masih kekal dan tak berubah walaupun dibakar pada suhu kebakaran setinggi $1100^{\circ} \mathrm{C}$. Berdasarkan kepada kajian ini, didapati protaip MBC ini sangat sesuai digunakan sebagai perisai perlindungan sinar pada kemudahan penyinaran terutamanya pada kemudahan sinar-X perubatan kerana mempunyai integriti pemerisaian sinaran yang tinggi walaupun berlakunya kebakaran bangunan atau bilik. 


\section{PENGHARGAAN}

Ucapan setinggi-tinggi penghargaan dan terima kasih kepada Jabatan Perkhidmatan Awam (JPA) Malaysia, Kementerian Sains Teknologi dan Inovasi (MOSTI) dan Agensi Nuklear Malaysia kerana memberikan hadiah latihan persekutuan (HLP) dan bantuan latihan dalam perkhidmatan dan kemudahan peralatan penyelidikan. Ucapan terima kasih juga ditujukan kepada Universiti Kebangsaan Malaysia (UKM) dan Pusat Penyelidikan dan Instrumentasi (CRIM) atas bantuan penggunaan peralatan penyelidikan dan kepakaran.

\section{RUJUKAN}

Amritphale, S.S., Anshul, A., Chandra, N. \& Ramakrishnan, N. 2007a. A novel process for making radiopaque materials using bauxite - red mud. Journal of European Ceramic Society 27: 1945-1951.

Amritphale, S.S., Anshul, A., Chandra, N. \& Ramakrishnan, N. 2007b. Development of celsian ceramics from fly ash useful for X-ray radiation-shielding application. Journal of European Ceramic Society 27(16): 4639-4647.

Bansal, N.P. 2003. Celsian formation in fiber-reinforced barium aluminosilicate glass-ceramic matrix composites. Materials Science and Engineering A32(2203): 23-27.

Bansal, N.P. \& Drummond, C.H. 1992. Kinetics of Hexacelsian to Celsian Phase Transformation in $\mathrm{SrAl}_{2} \mathrm{Si}_{2} \mathrm{O}_{8}$. National Aeronautics and Space Administration (NASA), E-7397.

Büermann, L. 2016. Determination of lead equivalent values according to IEC 61331-1:2014- report and short guidelines for testing laboratories. Journal of Instrumentation 11(9): T09002.

Drummond, C.H. \& Bansal, N.P. 1990. Crystalliation Behavior and Properties of BaO.Al2O3.2SiO2 Glass Matrices. National Aeronautics and Space Administration (NASA) Contractor Report 185209.

Filmore, D.L. 2004. Literature Review of the Effects of Radiation and Temperature on the Aging of Concrete. Idaho National Engineering and Environmental Laboratory Bechtel BWXT Idaho, LLC., INEEL/EXT-04-02319.

http://www.Infomine.com. 2017

h t tp: // ww w. ut u san.com.my/utusan/info. asp? $y=1998 \& d t=0716 \& p u b=$ Utusan_Malaysia\&sec $=$ Dal am\%5FNegeri\&pg=hn_04.htm. Kadar Kebakaran Masih Tinggi, Arkib 16/07/1998.
Kementerian Kesihatan Malaysia (KKM). 2017. Manual Perlaksanaan Program Jaminan Kualiti (QAP) dalam Perkhidmatan Radiologi. Putrajaya: Malaysia.

Keshk, A.B. \& Aly, R.A. 2012. Fire events effect on concrete shielding of Co-60 industrial irradiation facilities. Arab Journal of Nuclear Science and Applications 45(4): 109-121.

Kingrey, W.D. 1955. Factor affecting thermal stress resistance of ceramic materials. Journal of the American Ceramic Society 38(1): 3-15.

Kodur, V. 2014. Properties of concrete at elevated temperatures. ISRN Civil Engineering 2014: Article ID. 468510.

Ripin, A., Mohamed, F., Choo, T.F., Yusof, M.R., Hashim, S. \& Goshal, S.K. 2018. X-ray shielding behavior of kaolin derived mullite-barites ceramic. Journal of Radiation Physics and Chemistry 144: 63-68.

Rahim, M.S.N. 2015. The current trends and challenging situations on fire incident statistics. Journal of Forensic Sciences 6(1): 63-78.

Ouda, A.S. 2015. Development of high-performance heavy concrete using different aggregates for gamma-ray shielding. Journal of Progress in Nuclear Energy 79: 48-55.

TS EN 206-1, 2002. Concrete- Part: Specification, Performance, Production and Conformity TSE (Ankara: Turkey).

Azuhar Ripin

Medical Physics Group

Malaysia Nuclear Agency

43000 Kajang, Selangor Darul Ehsan

Malaysia

Azuhar Ripin, Faizal Mohamed*, Mohd Idzat Idris \& Nur Syafika Suhaimin

Nuclear Science Program

Faculty of Science and Technology

Universiti Kebangsaan Malaysia

43600 UKM Bangi, Selangor Darul Ehsan

Malaysia

*Pengarang untuk surat-menyurat; email: faizalm@ukm.edu.my

Diserahkan: 5 Jun 2018

Diterima: 29 Oktober 2018 